\title{
Disparitas Balita Kurang Gizi di Indonesia
}

\author{
Disparity of Under Nutrition Under Five in Indonesia
}

\author{
Sri Poedji Hastoety Djaiman ${ }^{1 *}$, Nunik Kusuma Wardhani ${ }^{1}$, Sihadi ${ }^{1}$, Kencana Sari ${ }^{1}$, \\ Dwi Siska Kumala Putri' ${ }^{1}$, Rika Rachmalina ${ }^{1}$, Nur Handayani Utami', Made Dewi Susilawati ${ }^{2}$, \\ Reviana Chitijani ${ }^{1}$, dan Febriani ${ }^{1}$ \\ ${ }^{1}$ Pusat Penelitian dan Pengembangan Upaya Kesehatan Masyarakat, Badan Penelitian dan Pengembangan \\ Kesehatan, Kementerian Kesehatan RI, Jl. Percetakan Negara No. 29 Jakarta Pusat, Indonesia \\ ${ }^{2}$ Pusat Penelitian dan Pengembangan Sumber Daya dan Pelayanan Kesehatan, Badan Penelitian dan \\ Pengembangan Kesehatan, Kementerian Kesehatan RI, Jl. Percetakan Negara No. 29 Jakarta Pusat, \\ Indonesia \\ Korespondensi Penulis: pujihadi@yahoo.com
}

Submitted:02-08-2018; Revised: 13-09-2018; Accepted: 17-09-2018

DOI: https://doi.org/10.22435/mpk.v28i3.219

\begin{abstract}
Abstrak
Kurang gizi mempunyai peran tidak hanya terhadap bertambahnya angka kesakitan dan kematian, tetapi juga terganggunya aspek psikososial dan perkembangan intelektual. Tiga kriteria kurang gizi yaitu underweight (berat kurang), stunting (pendek), dan wasting (kurus), mencerminkan kegagalan pertumbuhan baik di masa lalu maupun dimasa kini. Kegagalan pertumbuhan pada balita yang terjadi bersamaan sangat dipengaruhi oleh kondisi sosial ekonomi keluarga. Analisis ini membahas bagaimana disparitas pada anak kurang gizi di Indonesia dilihat dari dimensi sosial ekonomi rumah tangga. Analisis dilakukan dengan menggunakan data Riset Kesehatan Dasar (Riskesdas) 2013 yang diolah dengan menggunakan program Health Equity Assessment Toolkit (HEAT) yang dikeluarkan oleh WHO 2016. Dari analisis yang dilakukan prevalensi balita yang mengalami underweight, stunting, dan wasting secara bersamaan Composite Index of Anthropometric Failure (CIAF) sebesar 2,5\%. Semakin rendah status ekonomi rumah tangga semakin tinggi prevalensi balita mengalami CIAF. Balita dengan CIAF lebih banyak tinggal di perdesaan dibandingkan dengan balita CIAF yang tinggal di perkotaan. Masih ada 15 provinsi yang memiliki prevalensi balita CIAF lebih tinggi dari angka nasional. Balita CIAF lebih banyak terjadi pada ibu dengan tingkat pendidikan rendah dibandingkan dengan ibu yang mempunyai tingkat pendidikan cukup baik. Balita CIAF lebih banyak terjadi pada usia diatas 36 bulan dari pada usia dibawah 36 bulan. Dimensi provinsi memberikan perbedaan disparitas yang paling tinggi dibandingkan dengan dimensi lainnya.
\end{abstract}

Kata kunci : disparitas; kurang gizi; anak balita

\begin{abstract}
Malnutrition has a role not only to increase morbidity and mortality, but also to psychosocial aspects and intellectual development. Three criteria for malnutrition are: underweight, stunting and wasting, reflecting both past and present growth failures. Growth failure in children under five that occur simultaneously is strongly influenced by the socio-economic conditions of the family. This analysis discusses how disparities in malnourished children in Indonesia are seen from the socioeconomic dimensions of the household. The analysis was done by using Riskesdas 2013 data that was processed by using the HEAT (Health Equity Assessment Toolkit) program issued by WHO 2016. From the analysis, the prevalence of underweight, stunting and wasting simultaneously CIAF (Composite Index of Anthropometric Failure) was $2.5 \%$. The lower the economy the higher the prevalence of underfive children experiencing CIAF, under-fives with CIAF mostly live in rural areas compared to CIAF children under five living in urban areas. There are still 15 provinces that have a CIAF prevalence higher than the national figure. CIAF toddlers are more prevalent in mothers with lower level education compared to mothers who have a fairly good level of education. CIAF toddlers occur more common at age over 36 months from the age under 36 months. The provincial dimension gives the highest disparity compared to other dimensions
\end{abstract}

Keywords : disparity; malnutrition; under five 


\section{PENDAHULUAN}

Ketidak cukupan gizi atau sering dikenal sebagai kurang gizi mempunyai dampak yang sangat luas tidak hanya mempunyai peranan yang besar terhadap bertambahnya angka kesakitan dan kematian, tetapi mempunyai peranan terhadap terganggunya aspek psikososial dan perkembangan intelektual. Kekurangan gizi dapat menimpa siapa saja di masyarakat, namun bayi dan balita merupakan kelompok yang paling rawan mengalami kekurangan gizi karena kelompok ini memerlukan zat gizi yang tinggi untuk tumbuh kembang anak. ${ }^{1}$

Kondisi kurang gizi yang kronis pada seorang anak dapat menyebabkan stunting pada anak tersebut dimasa mendatang, seperti yang diungkapkan Hong, ${ }^{2}$ bagaimana kesenjangan ekonomi dikaitkan dengan kurang gizi kronis pada seorang anak di masa kecil mempunyai risiko mengalami stunting 2,5 kali dimasa selanjutnya. Lebih lanjut dari kondisi tersebut, pada anak stunting yang tidak tercukupi kebutuhan pangannya dan mengalami infeksi berulang dapat menyebabkan wasting atau berat badan tidak seimbang dengan tinggi badannya, bila hal ini tidak segera ditangani dapat menyebabkan terganggungnya fungsi sistem kekebalan tubuh dan dapat menyebabkan peningkatan tingkat keparahan dan durasi kerentanan terhadap penyakit menular yang pada akhirnya menyebabkan peningkatan risiko kematian. ${ }^{3}$

Kumar $^{4}$ melakukan analisis kurang gizi pada anak balita di Allahabad dari 62,8\% anak yang mengalami kegagalan pertumbuhan $5,9 \%$ diantaranya mengalami ketiga kegagalan pertumbuhan underweight, stunting, wasting/ Composite Index of Anthropometric Failure (CIAF). Artinya dari 100 anak balita, 62,8\% mengalami kekurangan gizi dan 5,9\% diantaranya mengalami kekurangan gizi dalam jangka yang panjang hingga saat ini. Di beberapa negara, CIAF telah digunakan untuk melakukan intervensi dalam mengatasi permasalahan kurang gizi pada anak balita.

Angka kekurangan gizi pada anak balita di Indonesia masih lebih tinggi dari beberapa negara Asean lainnya. Keterikatan erat antara kejadian kurang gizi pada balita dan kemiskinan mendorong pemerintah untuk mengatasi kemiskinan agar dapat menurunkan prevalensi kurang gizi pada anak balita. Dalam kurun waktu terakhir program kemiskinan selalu dikaitkan dengan prevalensi stunting pada anak balita. Untuk pemilihan wilayah intervensi prevalensi stunting masih dapat relevan, namun untuk menentukan intervensi sasaran penerima manfaat, kejadian stunting pada anak balita tidak selalu tepat oleh karena stunting merupakan gambaran kekurangan gizi yang panjang di masa lalu belum tentu pada saat ini masih mengalami hal yang sama. Untuk itu diperlukan suatu indikator yang lebih dapat menggambarkan kondisi kurang gizi pada masa lalu hingga saat ini. CIAF atau komposit kekurangan gizi/kegagalan pertumbuhan pada anak balita merupakan gambaran permasalahan kurang gizi anak dari waktu lampau hingga saat ini. Artikel ini akan menggali disparitas yang terjadi pada anak balita yang mengalami ketiga masalah kurang gizi tersebut secara bersamaan, sehingga dapat memberikan gambaran bagaimana keterkaitan antara status sosial ekonomi penduduk terhadap permasalahan balita yang mengalami kegagalan pertumbuhan dalam jangka panjang hingga saat ini.

\section{METODE}

Artikel ini akan membahas tentang disparitas yang terjadi pada anak balita kurang gizi. Analisis disparitas menggunakan data Riset Kesehatan Dasar (Riskesdas) 2013 yang diolah dengan program Health Equity Assessment Toolkit (HEAT) yang dikeluarkan oleh WHO 2016. ${ }^{5}$ Ada lima dimensi yang dianalisis untuk melihat kesenjangan tersebut yaitu: (1)status ekonomi rumah tangga, (2) tempat tinggal, (3) provinsi, (4) tingkat pendidikan ibu, (5) usia balita.

Uji statistik yang digunakan untuk menguji disparitas adalah uji simple inequity dan analisis complex inequity. ${ }^{5}$ Riskesdas merupakan survei dengan desain cross sectional dilakukan lima tahun sekali, serentak di 33 provinsi seluruh Indonesia, dengan total sampel 294.959 rumah tangga dan 1.027.763 individu. Dari jumlah individu tersebut, 82.666 merupakan kelompok umur balita, secara keseluruhan dianalisis dalam artikel ini. ${ }^{6}$

Beberapa batasan yang digunakan dalam analisis ini mengacu pada SK Menkes No.1995/ Menkes/SK/XII/20107:

1. Underweight pada anak balita adalah suatu keadaan dimana anak balita mengalami gizi kurang atau gizi buruk (gizi kurang bila BB/U antara -3 SD sampai dengan -2 SD dan gizi buruk $\mathrm{BB} / \mathrm{U} \leq 3 \mathrm{SD}$ ).

2. Stunting pada anak balita adalah suatu keadaan dimana anak balita mengalami pendek atau sangat pendek (pendek bila TB/U antara -3 SD 
sampai dengan -2 SD dan sangat pendek bila $\mathrm{TB} / \mathrm{U} \leq-3 \mathrm{SD}$ ).

3. Wasting adalah suatu keadaan dimana anak balita mengalami kurus dan sangat kurus (kurus bila $\mathrm{BB} / \mathrm{TB}$ antara $-3 \mathrm{SD}$ sampai dengan $-2 \mathrm{SD}$ dan sangat kurus bila $\mathrm{BB} / \mathrm{TB} \leq$ $-3 \mathrm{SD})$.

4. Composite Index Antropometri Failure (CIAF) adalah suatu keadaan dimana seorang anak mengalami ketiga kegagalan pertumbuhan underweight, stunting dan wasting.

5. Anak balita adalah anak berusia 0 - 59 bulan berdasarkan ulang tahun terakhir.

\section{HASIL}

\section{Gambaran Kurang Gizi pada Anak Balita di Indonesia}

Kekurangan gizi pada anak balita merupakan suatu kondisi yang mencerminkan keadaan pertumbuhan anak balita, yang diukur berdasarkan berat badan anak dan tinggi badan anak yang dikaitkan dengan umur, seperti indeks $\mathrm{BB} / \mathrm{U}$ (berat badan berdasarkan umur), $\mathrm{TB} / \mathrm{U}$ (tinggi badan berdasarkan umur) dan $\mathrm{BB} / \mathrm{TB}$ (berat badan berdasarkan tinggi badan). Riskesdas merupakan suatu survei berskala nasional yang mengumpulkan data antropometri secara lengkap dan dapat merepresentatifkan hingga tingkat kabupaten/kota. Berdasarkan Riskedas 2007 dan Riskesdas 2013 status gizi pada anak balita di Indonesia cenderung menunjukkan peningkatan kecuali persentase stunting. Gambaran permasalahan kurang gizi pada anak balita di Indonesia sejak tahun 2007 dan tahun 2013 dapat dilihat Tabel 1.

Dari Tabel 1 nampak prevalensi underweight tahun 2007 sebesar 18,4\% tahun 2013 meningkat menjadi 19,9\%. Pola tersebut tidak jauh berbeda dengan persentase stunting. Persentase stunting tahun 2007 sebesar 36,8\% dan tahun 2013 meningkat menjadi 37,2\%. Hal tersebut berbeda dengan persentase wasting, tahun 2007 persentase wasting pada anak balita 13,6\% dan menurun pada tahun 2013 menjadi 12,1\%., Walaupun beberapa angka kurang gizi pada anak balita menunjukkan penurunan, namun angka tersebut masih di atas standar permasalahan gizi masyarakat (stunting lebih $20 \%$ dan wasting di atas $5 \%)^{9}$

Cukup seriusnya permasalahan kurang gizi pada anak balita (terutama masalah stunting) mendorong pemerintah bergerak cepat untuk dapat mengatasi hal tersebut. Permasalahannya adalah keterbatasan sumber daya yang dimiliki pemerintah mengharuskan adanya skala prioritas.
Stunting merupakan keadaan kurang gizi yang merefleksikan kondisi kurang gizi yang panjang di masa lalu yang banyak terkait dengan masalah ekonomi rumah tangga, namun kondisi tersebut belum tentu berlanjut hingga saat ini (Lihat Tabel 2).

Dari $37,2 \%$ balita stunting di Indonesia hanya $13,0 \%$ yang mengalami status gizi kurang dilihat berat badan berdasarkan umur dan 2,5\% yang mengalami kurus berdasar kanberat badan dibandingkan tinggi badan. ${ }^{4}$ Artinya hanya ada $13,0 \%$ dan $2,5 \%$ anak balita yang mengalami kurang gizi dari waktu yang lama hingga saat ini, untuk itu penggunaan stunting sebagai fokus intervensi diperlukan adanya suatu kehati-hatian. Penanganan balita dengan stunting harus lebih spesifik dengan tetap memperhatikan kondisi kurang gizi pada saat ini. Berdasarkan Riskesdas 2013 ada 2,5\% anak balita di Indonesia mengalami underweight, stunting, dan sekaligus wasting.

\section{Disparitas dan Inequity Masalah Indeks Kom- posit Kurang Gizi di Indonesia}

Indeks Komposit Kurang Gizi atau Composite Index of Antrophometry Failure (CIAF) adalah suatu keadaan dimana seseorang mengalami masalah kurang gizi ketiganya (underweight, stunting, dan wasting). Faktor ekonomi adalah adalah akar masalah dari kurang gizi tersebut. Berikut ini adalah gambaran bagaimana ketimpangan yang terjadi pada beberapa faktor sosial ekonomi demografi, termasuk kelompok umur, kuintil ekonomi, pendidikan, tempat tinggal (perkotaan-pedesaan), dan provinsi.

Gambar 1 menunjukkan bagaimana disparitas yang terjadi pada balita indeks kurang gizi berdasarkan status ekonomi keluarga. Semakin baik status ekonomi keluarga semakin rendah proporsi balita yang kurang gizi.

Gambar 2 menunjukkan anak balita yang tinggal di perdesaan mempunyai persentase indeks kurang gizi lebih tinggi dibandingkan dengan balita yang tinggal di perkotaan.

Pada Gambar 3 tampak bahwa ratarata proporsi indeks kurang gizi pada balita di Indonesia adalah sebesar 2,5\% dengan proporsi tertinggi di Maluku dan terendah di DKI Jakarta. Dapat dilihat juga bahwa angka proporsi di atas nilai rata-rata nasional didominasi oleh provinsi di wilayah Indonesia bagian timur. Masalah gizi masih menjadi masalah utama yang terus berlanjut selama bertahun-tahun di sebagian provinsi di wilayah timur. 
Tabel 1. Persentase Status Gizi Berdasarkan Indeks Antropometri dan Tahun

\begin{tabular}{|c|c|c|c|c|}
\hline $\begin{array}{c}\text { Tahun } \\
\text { Pengumpulan Data }\end{array}$ & $\begin{array}{c}\text { Indeks } \\
\text { Antropometri }\end{array}$ & $\begin{array}{c}\text { Status } \\
\text { Gizi }\end{array}$ & Persentase & Total \\
\hline \multirow[t]{9}{*}{$2007^{8}$} & $\mathrm{BB} / \mathrm{U}$ & Buruk & 5,4 & \\
\hline & & Kurang & 13,0 & \\
\hline & & Underweight & & 18,4 \\
\hline & $T B / U$ & Sangat pendek & 18,8 & \\
\hline & & Pendek & 18,0 & \\
\hline & & Stunting & & 36,8 \\
\hline & $\mathrm{BB} / \mathrm{TB}$ & Sangat kurus & 6,2 & \\
\hline & & Kurus & 7,4 & \\
\hline & & Wasting & & 13,6 \\
\hline \multirow[t]{9}{*}{$2013^{9}$} & $\mathrm{BB} / \mathrm{U}$ & Buruk & 5,7 & \\
\hline & & Kurang & 13,9 & \\
\hline & & Underweight & & 19,6 \\
\hline & $T B / U$ & Sangat pendek & 18,0 & \\
\hline & & Pendek & 19,2 & \\
\hline & & Stunting & & 37,2 \\
\hline & $\mathrm{BB} / \mathrm{TB}$ & Sangat kurus & 5,3 & \\
\hline & & Kurus & 6,8 & \\
\hline & & Wasting & & 12,1 \\
\hline
\end{tabular}

Tabel 2. Persentase Balita Stunting Berdasarkan Status Gizi Underweight dan Wasting

\begin{tabular}{llc}
\hline & & Stunting (37,2\%) \\
\hline Underweight & Kurang & $13,0 \%$ \\
& Baik & $23,3 \%$ \\
Wasting & Lebih & $0,9 \%$ \\
& & \\
& Kurang & $2,5 \%$ \\
& Normal & $27,5 \%$ \\
& Gemuk & $7,2 \%$ \\
\hline
\end{tabular}

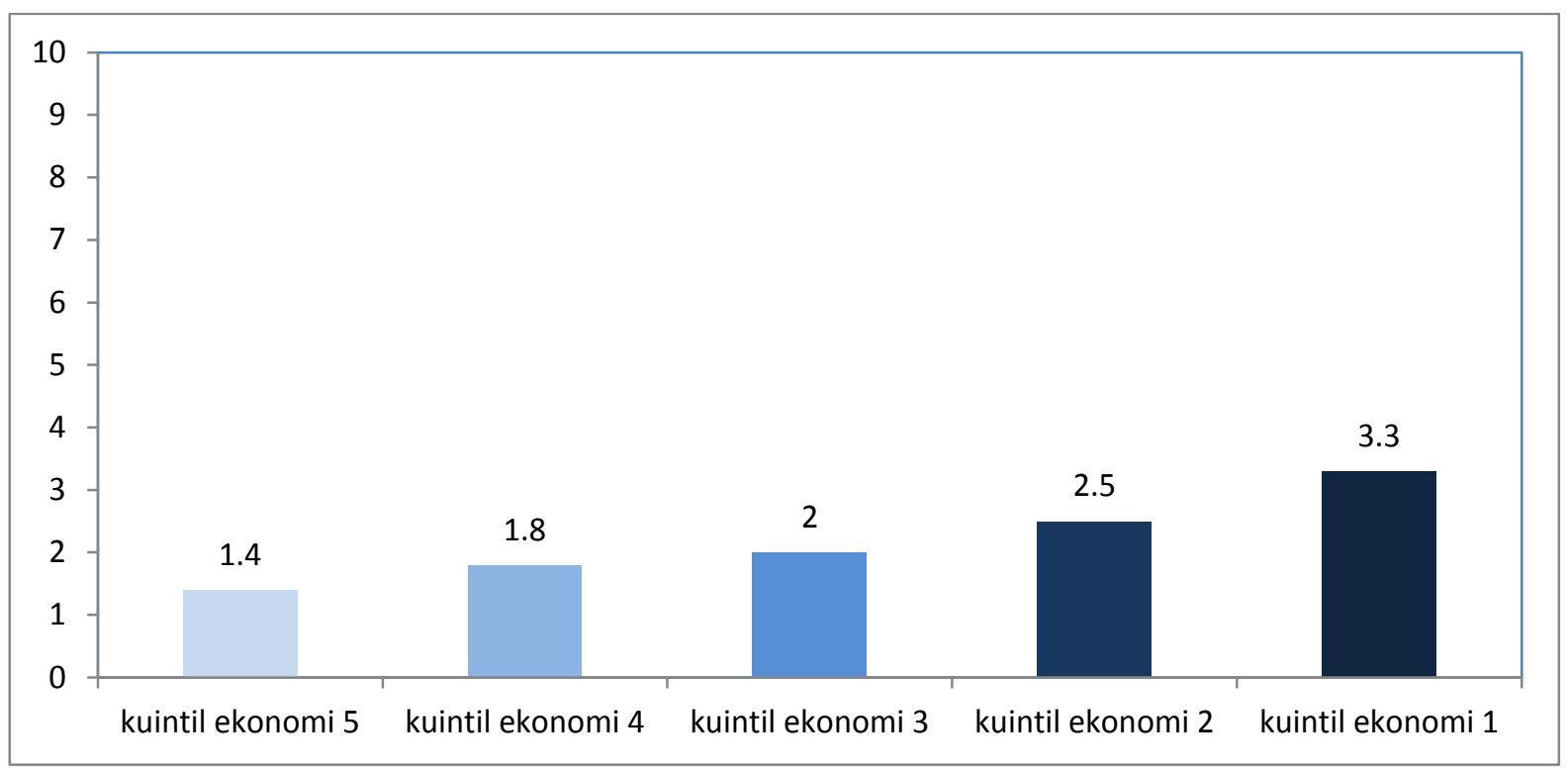

Gambar 1. Proporsi Balita dengan Indeks CIAF Berdasarkan Status Ekonomi Rumah Tangga 


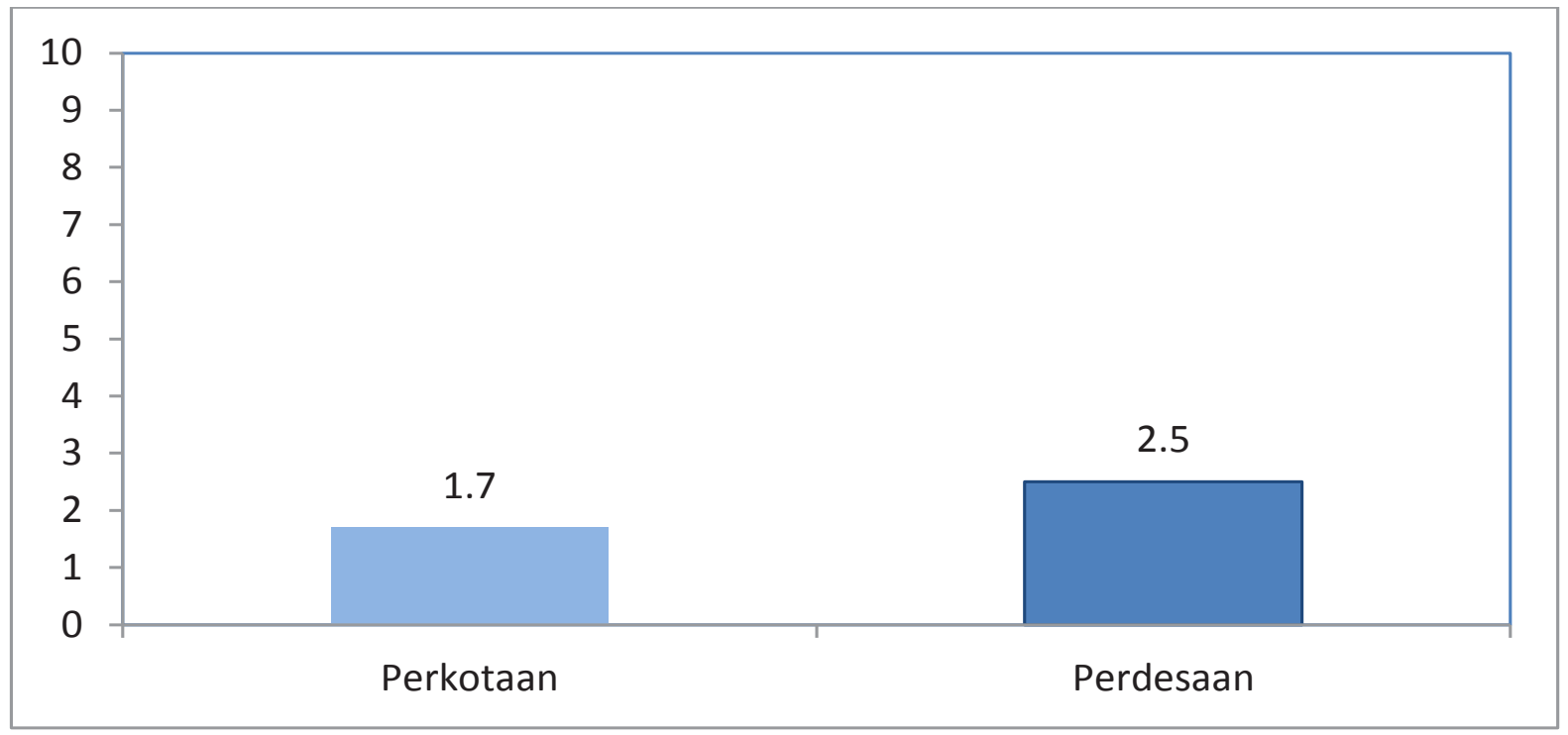

Gambar 2. Proporsi Balita dengan CIAF berdasarkan Status Tempat Tinggal

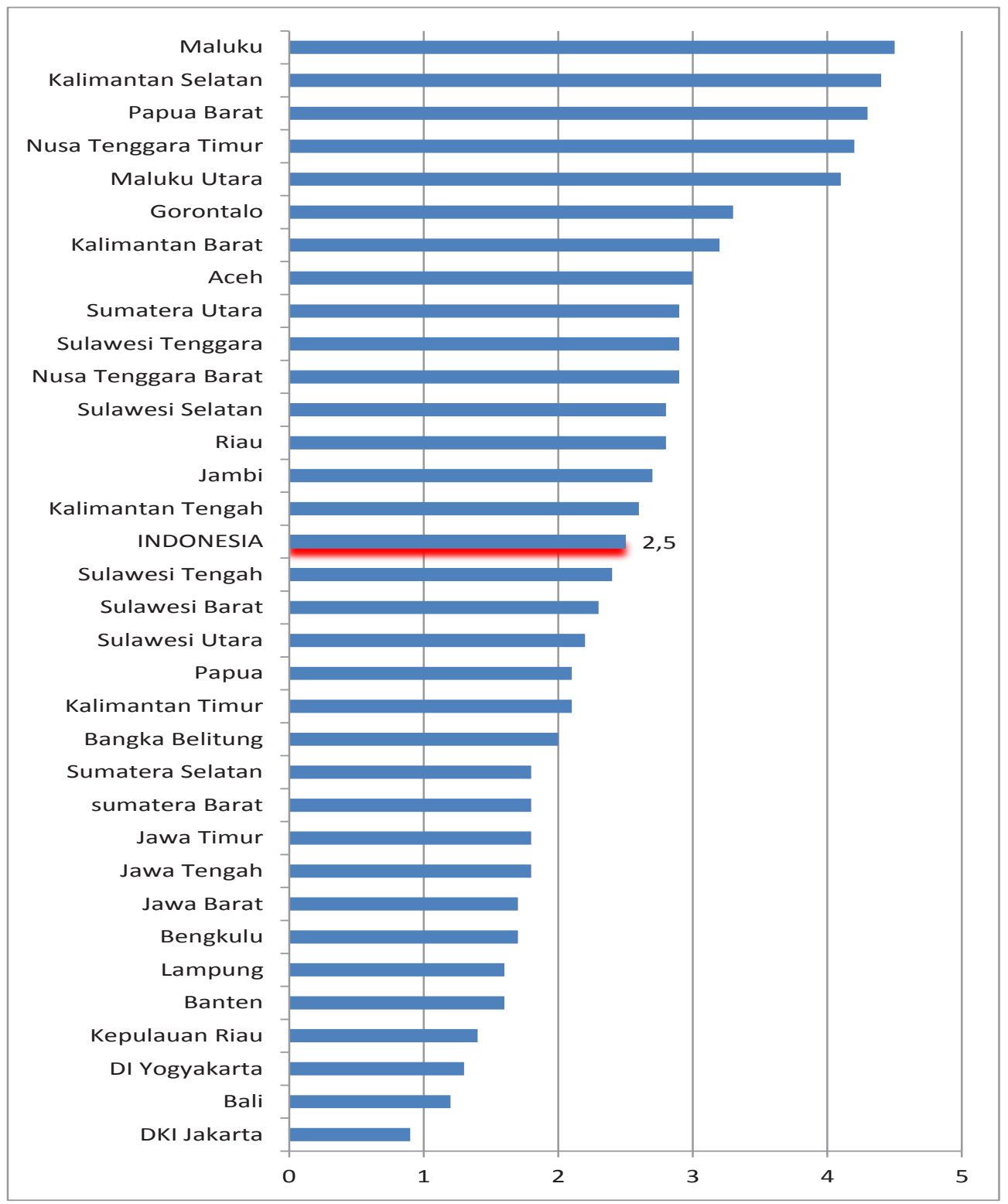

Gambar 3. Proporsi Balita dengan CIAF Berdasarkan Provinsi 


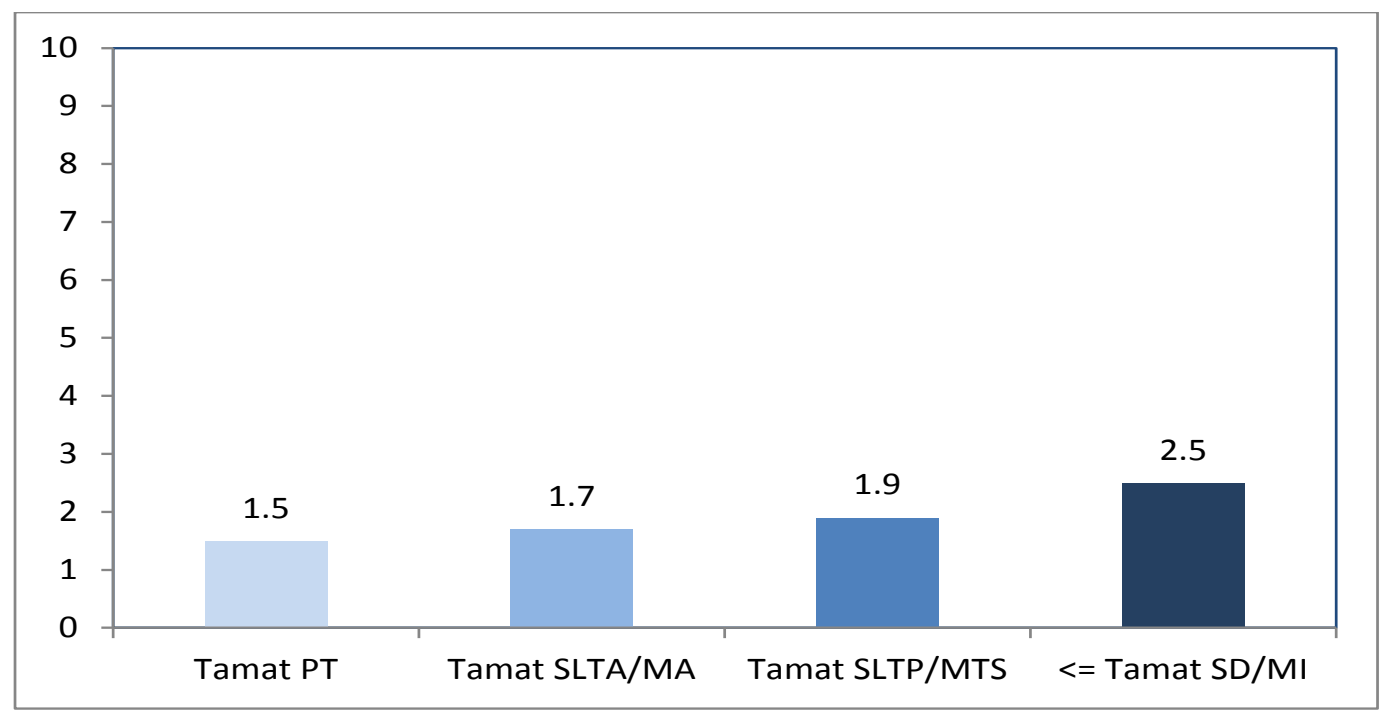

Gambar 4. Proporsi Balita dengan CIAF Berdasarkan Tingkat Pendidikan Ibu

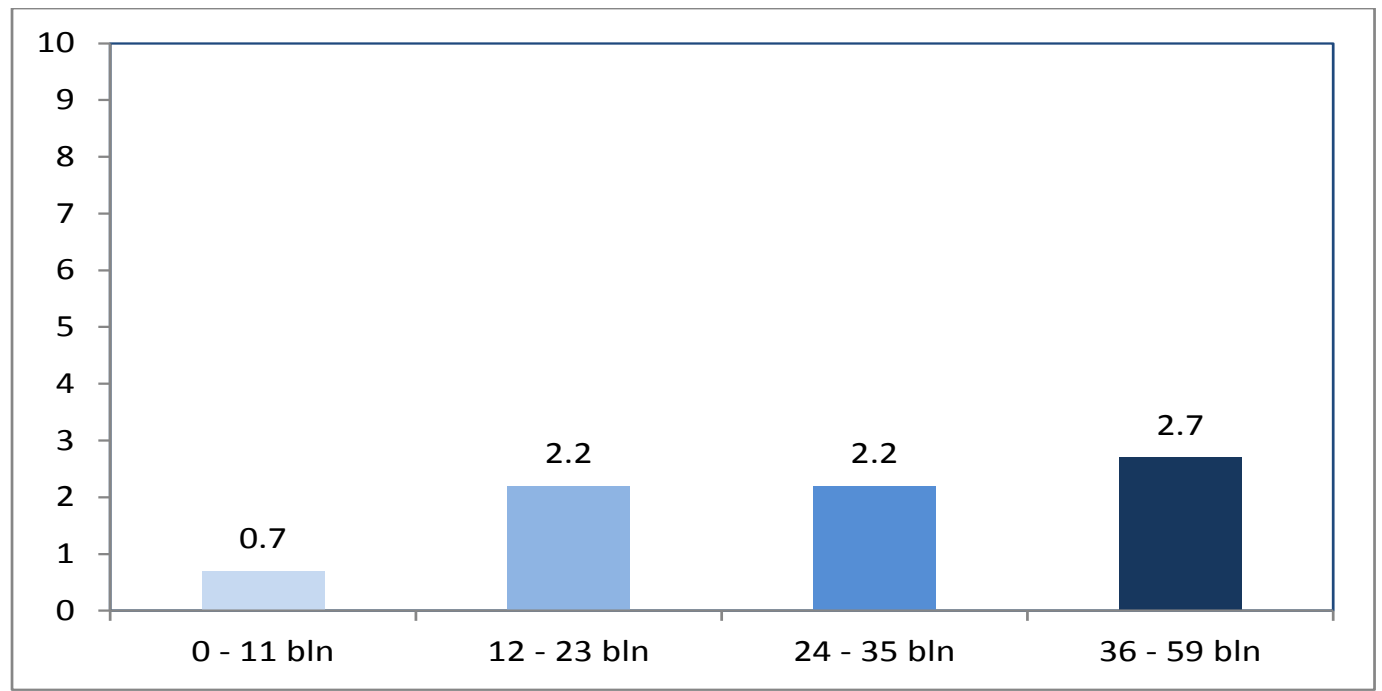

Gambar 5. Proporsi Balita dengan CIAF Berdasarkan Umur Balita

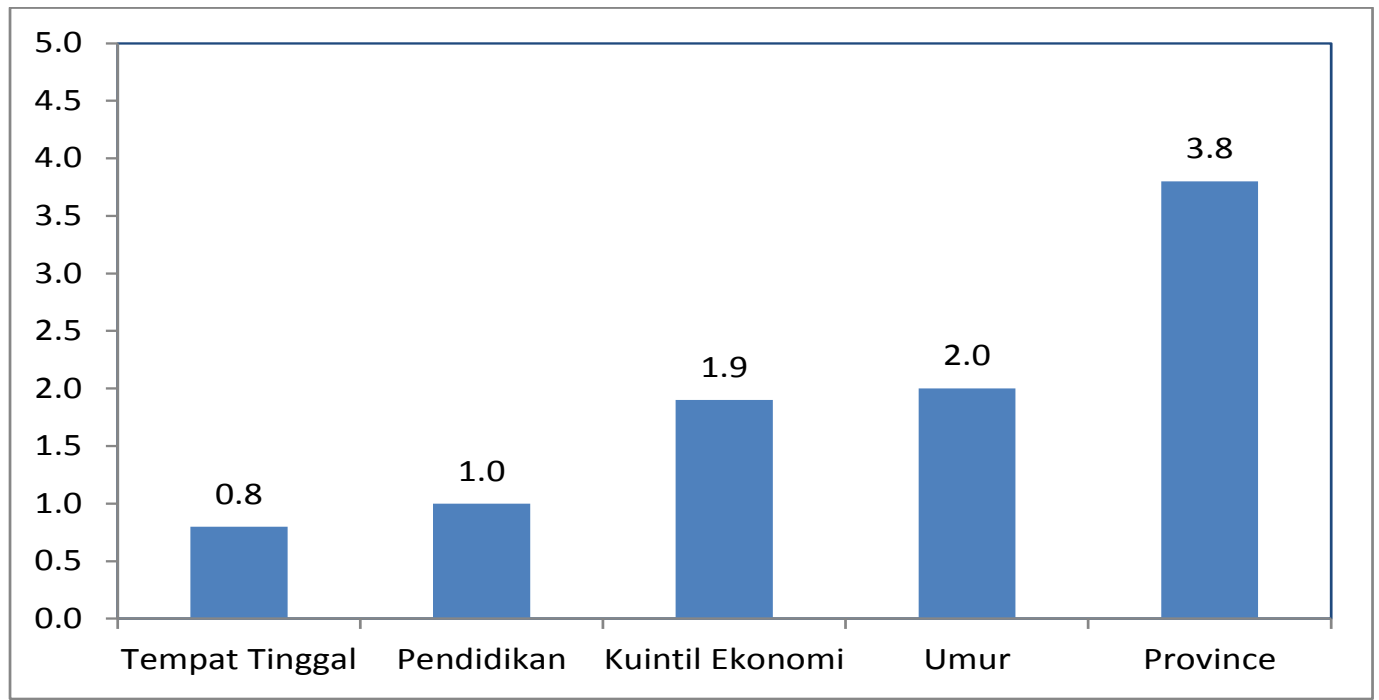

Gambar 6. Nilai Inequity Proporsi CIAF Berdasarkan Nilai Mean Beberapa Faktor Sosial Demografi 
Tabel 3. Hasil Analisis Complex Inequality untuk Kelompok Umur, Pendidikan, dan Ekonomi

\begin{tabular}{lcc}
\hline \multicolumn{1}{c}{ Dimensi } & SII* & MDB** $^{* *}$ \\
\hline Kelompok Umur Balita (bulan) & 1,3 & \\
Pendidikan & 1,6 & \\
Ekonomi & 2,3 & 1,6 \\
Provinsi & & 1,6 \\
\hline
\end{tabular}

* SII: Slope Index of Inequality

**MDB: Mean Difference of the Best Performance Sub Group

Gambar 4 menunjukkan bahwa proporsi indeks kurang gizi pada balita tampak lebih tinggi pada populasi ibu dengan rata-rata pendidikan rendah atau tamat/tidak tamat sekolah dasar.

Gambar 5 menunjukkan bahwa bila dibandingkan antara beberapa kelompok umur balita, maka kelompok balita yang lebih tua (36 - 59 bulan) mempunyai proporsi indeks kurang gizi balita yang lebih tinggi dibandingkan balita yang lebih muda.

Gambar 6 menunjukkan hasil analisis inequity menggunakan instrumen HEAT (WHO 2016) menunjukkan bahwa perbedaan angka proporsi indeks status kurang gizi menunjukkan perbedaan yang tertinggi pada proporsi antara provinsi, diikuti oleh perbedaan proporsi antara kelompok umur dan kuintil ekonomi.

Sementara itu hasil analisis complex inequality menunjukkan angka SII yang cukup tinggi pada dimensi status ekonomi (Tabel 3). Hal ini menunjukkan bahwa perbedaan proporsi Indeks Komposit Status Kurang Gizi atau inequality yang terjadi antara kuintil ekonomi 1, 2, 3, 4, dan 5 adalah sebesar 2,3 poin, dengan angka proporsi yang lebih tinggi dengan status ekonomi yang lebih rendah. Angka inequalty berdasarkan tingkat pendidikan yang berbeda adalah sebesar 1,6 poin. Hal ini berarti perbedaan angka inequality proporsi komposit status kurang gizi adalah sebesar 1,6 poin antara empat kelompok tingkat pendidikan (sekolah dasar atau lebih rendah, lulus SMP, lulus SMA, dan lulus D3 atau lebih tinggi) dimana semakin rendah tingkat pendidikan semakin tinggi angka permasalah status kurang gizi.

Pada Tabel 3 juga dapat dilihat untuk hasil inequality proporsi indeks status kurang gizi diantara 33 provinsi. Hasil uji MDB menunjukkan perbedaan rata-rata proporsi adalah sebesar 16 poin, dengan perbandingan provinsi yang memiliki proporsi indeks status kurang gizi terendah yaitu di Provinsi DKI Jakarta. Ratarata perbedaan angka proporsi di 32 provinsi lainnya dibandingkan dengan angka proporsi di DKI Jakarta adalah sebesar 1,6 poin. Perbedaan proporsi terlebar adalah antara Provinsi DKI Jakarta dan Maluku.

\section{PEMBAHASAN}

Semakin baik status ekonomi keluarga semakin rendah proporsi balita yang kurang gizi. Hal tersebut dapat terjadi oleh karena hampir seluruh determinan yang menyebabkan anak dapat menderita kurang gizi sangat terkait dengan kondisi ekonomi suatu keluarga, seperti akses rumah tangga terhadap pangan bergizi, serta kondisi rumah dan lingkungan yang sehat. Tingkat status sosial ekonomi dapat memengaruhi asupan makan balita. Hasil penelitian ini sejalan dengan penelitian Pujiati dkk, ${ }^{10}$ bahwa didapatkan hasil besar risiko status ekonomi terhadap kejadian gizi buruk pada anak balita adalah 9,514. Arti bahwa balita dengan status sosial ekonomi keluarga rendah memiliki risiko 9,514 kali dibandingkan balita dengan status ekonomi keluarga tinggi untuk menjadi gizi buruk. Demikian juga penelitian Myrnawati dan Anita, ${ }^{11}$ yaitu status sosial ekonomi keluarga berpengaruh langsung positif terhadap status gizi anak usia sekolah PAUD di Semarang. Lebih lanjut penelitian faktor demografi dan risiko gizi buruk dan gizi kurang oleh Saputa $\mathrm{dkk}^{12}$ menyimpulkan bahwa, faktor kemiskinan dan rendahnya tingkat pendidikan orang tua merupakan faktor utama dalam risiko balita menderita gizi buruk dan gizi kurang. Menurut Wigati, ${ }^{13}$ ekonomi bukan satu-satunya yang dapat mengatasi masalah gizi buruk. Ada faktor lain seperti budaya, pasar, pola asuh, pengetahuan masyarakat tentang kesehatan, pantangan dan lain-lain yang harus diperhatikan 
juga dalam menangani anak balita gizi buruk.

Diperkirakan tingginya proporsi kurang gizi di Provinsi Maluku terutama akses ke pelayanan kesehatan relatif sulit, mengingat dari 9 kabupaten dan 2 kota di Maluku, tiga kabupaten diantaranya termasuk Daerah Tertinggal, Perbatasan, dan Kepulauan (DTPK) dan Daerah Bermasalah Kesehatan (DBK), dan 5 kabupaten lainnya termasuk daerah DBK. ${ }^{14}$ Status ekonomi, pendidikan dan akses terhadap pangan bergizi menjadi faktor determinan yang mempengaruhi status gizi balita.

Tingkat pendidikan cukup berperan dalam status gizi balita. Hal ini berkaitan dengan semakin tinggi tingkat pendidikan ibu maka semakin tinggi kesempatan ibu untuk mendapatkan akses yang memadai terhadap pengetahuan kesehatan dan lebih mempunyai keterampilan kesehatan dalam praktek pola asuh balita yang sehat. Menurut Aramico dkk, ${ }^{15}$ bahwa pendidikan orang tua yang tinggi dapat mengubah pola makan seseorang yang pada akhirnya berpengaruh terhadap status gizi keluarga termasuk anak. Penelitian risiko pendidikan ibu terhadap kejadian stunting anak 6-23 bulan di Banjarbaru yang dilakukan Rahayu $\mathrm{dkk}^{16}$ menunjukkan, bahwa risiko ibu dengan tingkat pendidikan rendah berisiko 5,1 kali lebih besar memiliki anak stunting. Pendidikan ibu mempunyai peranan penting dalam kejadian anak stunting $(p<0.05)$. Perbedaan beberapa karakteristik sosioekonomi terhadap kejadian balita gizi kurang juga sangat dirasakan di negara Bangladesh dan Nepal. Data Demographic Health and Surveys (DHS) pada kedua negara tersebut menunjukkan karakteristik sosioekonomi terutama yang berkaitan dengan pendidikan ibu dan indeks kekayaan memberikan pengaruh yang kuat terhadap tingginya angka kurang gizi pada anak balita di kedua negara tersebut. ${ }^{17}$

Tidak mudah mengubah pola pikir dan perilaku yang telah lama menjadi tradisi masyarakat. Begitu pentingnya pengaruh unsur pendidikan Widodo dkk, ${ }^{18}$ dalam penelitiannya intervensi penanggulangan kurang gizi pada anak balita lebih ditekankan edukasi lewat program PERGIZI (Program Edukasi dan Rehabilitasi Gizi). Penyelenggaraan kegiatan PERGIZI selama 24 minggu dapat membantu peningkatan status gizi dan kesehatan anak balita.
Nilai proporsi pada kelompok usia termuda (0-11 bulan) cenderung jauh lebih rendah, yang kemungkinan berkaitan dengan masih terpenuhinya kebutuhan gizi dari susu, baik Air Susu Ibu (ASI) maupun susu formula dan diperkirakan aktivitasnya lebih rendah dibandingkan kelompok usia diatasnya. Sementara pada balita yang lebih tua, usia tiga tahun ke atas, merupakan masa di mana balita sudah mulai lebih banyak beraktifitas fisik dan terpapar lingkungan sekitarnya. Penelitian ini sejalan dengan hasil penelitian Sukoco dkk, ${ }^{19}$ yaitu hasilnya terdapat perbedaan yang bermakna $(p<0,05)$ pada status gizi balita dengan indikator berat badan menurut umur $(\mathrm{BB} / \mathrm{U})$, masalah gizi kurang banyak terjadi pada rentang usia di atas 3 tahun hingga mendekati usia 5 tahun. Di samping itu, hal ini menunjukkan kemungkinan sudah mulai terdeteksinya kasus stunting atau pendek.

Pada Gambar 5 selisih proporsi tertinggi dan terendah pada kelompok umur adalah sebesar 2 poin, dimana proporsi pada kelompok umur muda $(0-11$ bulan) adalah proporsi yang terendah $(0,7 \%)$ dan proporsi tertinggi $(2,7 \%)$ adalah pada kelompok umur balita tua $(35-59$ bulan). Sementara untuk perbedaan proporsi antara kelompok kuintil ekonomi (Gambar 4), menunjukkan perbedaan proporsi tertinggi $(3,3 \%$ pada kuintil 1) dengan proporsi terendah $(1,4 \%$ pada kuintil 5) dengan angka hasil uji simple inequality sebesar 1,9 poin.

\section{KESIMPULAN}

Anak balita kurang gizi data tahun 2013 untuk underweight sebesar 19,6\%, stunting $37,2 \%$ dan wasting $12,1 \%$, dan yang mengalami underweight, stunting dan wasting sebesar 2,5\%. Secara disparitas, maka semakin baik status ekonomi keluarga semakin rendah proporsi balita yang kurang gizi. Anak balita yang tinggal di perdesaan mempunyai persentase indeks kurang gizi lebih tinggi dibandingkan tinggal di perkotaan. Berdasarkan provinsi, maka ratarata indeks kurang gizi di Indonesia sebesar 2,5\%, dengan persentase tertinggi di Provinsi Maluku dan terendah di DKI Jakarta. Semakin tinggi tingkat pendidikan ibu, semakin rendah persentase indeks kurang gizi pada anak balita. Semakin tinggi umur anak balita, semakin tinggi 
persentase indeks anak balita kurang gizi. Hasil analisis complex inequity menunjukkan angka SII yang cukup tinggi pada dimensi ekonomi.

\section{SARAN}

Dalam penanggulangan dan pencegahan anak balita kurang gizi, sebaiknya lebih diprioritaskan pada masyarakat golongan ekonomi tidak mampu dan tinggal di perdesaan, tingkat pendidikan orang tua yang relatif rendah, dan anak balita umur 3-5 tahun. Jika dilihat berdasarkan provinsi, yang perlu mendapat perhatian adalah Provinsi Maluku.

\section{UCAPAN TERIMA KASIH}

Terima kasih diucapkan kepada Ibu Julianti Pradono atas koreksi dan masukan untuk artikel ini, sehingga artikel ini menjadi lebih baik.

\section{DAFTAR PUSTAKA}

1. Blossner $\mathrm{M}$, de Onis M. Malnutrition quantifying the health impact at national and local levels. Geneva: World Health Organization; 2005.

2. Hong R, Vinod M. Effect of wealth inequality on chonic under nutrition in Cambodian children. J Health Popul Nutr. 2006;24(1):8999. 2006 ICDDR,B: Centre for Health and Population Research.

3. WHO. Nutrition landscape information system (NLIS) country profile indicator. WHO Library Cataloguing in Publication Data. 20 Avenue Appia, 1211 Geneva 27, Switzerland; 2010.

4. Kumar D, Mittal PC, Sharma MK. Socio-demographic risk factors of child undernutrition. Journal of Pediatric Sciences 2010;2:e7.

5. WHO. Health inequality monitoring with a special focus on low and middleincome countries. Geneva: World Health Organization; 2013.

6. Badan Penelitian dan Pengembangan Kesehatan. Riset kesehatan dasar (Riskesdas) 2013. Jakarta: Badan Penelitian dan Pengembangan, Kementerian Kesehatan RI; 2013.

7. Kementerian Kesehatan. Keputusan Menteri Kesehatan Republik Indonesia Nomor. 1995/Menkes/SK/XII/2010 tentang standar antropometri penilaian status gizi anak. Jakarta: Direktorat Bina Gizi; 2011.

8. Badan Penelitian dan Pengembangan Kesehatan. Riset Kesehatan Dasar (Riskesdas) 2007: Laporan Nasional. Jakarta: Badan Penelitian dan Pengembangan Kesehatan, Departemen Kesehatan RI;2008.

9. Direktorat Gizi Masyarakat, Direktorat Jenderal Kesehatan Masyarakat. Buku saku pemantuan status gizi tahun 2017. Jakarta: Direktorat Gizi Masyarakat, Direktorat Jenderal Kesehatan Masyarakat, Kementerian Kesehatan RI.; 2018.

10. Pujiati K, Dian SA, Indra D. Identifikasi kasus kekurangan gizi pada anak di bawah usia lima tahun di kota Makassar. Jurnal Fakultas Kesehatan Masyarakat. 2017;11(2):140-145.

11. Myrnawati, Anita. Pengaruh pengetahuan gizi, status sosial ekonomi, gaya hidup dan pola makan terhadap status gizi (Studi kausal di Pos PAUD Kota Semarang tahun 2015). Jurnal Pendididikan Usia Dini. 2016;10(2):213-232.

12. Saputra W, Rahmah HN. Faktor demografi dan risiko gizi buruk dan gizi kurang. Makara Kesehatan. 2012;16(2):95-101.

13. Wigati TR. Fenomena gizi buruk pada keluarga dengan status ekonomi baik: sebuah studi tentang negative deviance di Indonesia. The Indonesian Journal of Public Health. 2009;5(3):89-93.

14. Dinas Kesehatan Provinsi Maluku. Profil kesehatan provinsi Maluku tahun 2014. Ambon: Dinas Kesehatan Provinsi Maluku; 2015.

15. Aramico B, Toto S, Joko S. Hubungan sosial ekonomi, pola asuh, pola makan dengan stunting pada siswa sekolah dasar di Kecamatan Lut Tawar, Kabupaten Aceh Tengah. Jurnal Gizi dan Dietetik Indonesia. 2013;1(3):121-130.

16. Rahayu A, Laily K. Risiko pendidikan ibu terhadap kejadian stunting pada anak 6-23 bulan. Penel Gizi Makan. Desember 2014;37(2):129-136.

17. Srinivasan CS, Glaemo Z, Bhavani S. Rural urban disparities in child nutrition in Bangladesh and Nepal. BMC Public Health. 2013;13:581-596. 
18. Widodo Y, Sri M, Salimar. Partisipasi masyarakat dalam rehabilitasi anak balita kurang gizi melalui program edukasi dan rehabilitasi gizi (PERGIZI). Penel Gizi Makan 2012;35(2):136-149.
19. Sukoco NEW, Joko P, Maria HH. Hubungan status gizi anak balita dengan orang tua bekerja. Bul Penel Sistem Kes. 2015;18(4): 387-397. 